\title{
Penerapan Nilai-Nilai Syariah Pada Pegadaian Syariah Unit Kampung Solok Muara Bungo
}

\author{
Rena Yuliyani ${ }^{1}$ \\ Institut Agama Islam YasniBungo \\ E-Mail: rena.yulianisunshine28@gmail.com
}

Ainil Fhadilah ${ }^{2}$

Institut Agama Islam YasniMuaraBungo

E-Mail: ainilfhadilah@gmail.com

\begin{abstract}
Shari'ah values should be applied to all agencies, especially in the Shari ah Pawnshop Unit of Kampung Solok Muara Bungo. The purpose of writing this thesis is to see the extent of implementation in the application of shari ah values in the Shari ah Pegadaian Unit of Kampung Solok Muara Bungo. The main problem in this research is how is the implementation in the application of shari ah values at the Shari ah Pegadaian Unit Kampung Solok Muara Bungo. The methodology used is a qualitative research method with a descriptive approach. The object of research at the Office of the Sharia Pawnshop Unit in Kampung Solok Muara Bungo. There are two types and sources of data in the study, namely primary data and secondary data. There are three techniques in data collection, namely observation, interview and documentation. There are three techniques in data analysis, namely data reduction, data presentation and verification. To check the validity of the data on these findings, researchers used lengthening observations, increasing persistence, and triangulation. The results showed that the Shariah Pegadaian Unit Kampung Solok Muara Bungo has implemented all the values of shari'ah and the values of the pawnshop itself. It's just not perfect because there are still things that have not been done well, namely using technology properly and not carrying out morning prayers every day.
\end{abstract}

Keywords: Sharia Values, Sharia Pawnshops

\begin{abstract}
Abstrak
Nilai-nilai syari ah seharusnya diterapkan pada semua instansi terutama pada Pegadaian Syari'ah Unit Kampung Solok Muara Bungo. Tujuan dalam penulisan skripsi ini adalah untuk melihat sejauh mana implementasi dalam penerapan nilai-nilai syari'ah pada Pegadaian Syari'ah Unit Kampung Solok Muara Bungo. Pokok permasalahan dalam penelitian ini adalah bagaimanakah implementasi dalam penerapan nilai-nilai syari`ah pada Pegadaian Syari ah Unit Kampung Solok Muara Bungo. Metodologi yang digunakan adalah metode penelitian kualitatif dengan pendekatan deskriptif. Objekpenelitiandi Kantor Unit Pegadaian Syariah Kampung Solok Muara Bungo. Jenis dan sumber data dalam penelitian yang digunakan ada dua yaitu data primer dan data sekunder. Ada tiga teknik dalam pegumpulan data yaitu observasi, wawancara dan dokumentasi. Ada tiga teknik dalam analisis data yaitu reduksi data, penyajian data dan verifikasi. Untuk mengecek keabsahan data pada temuan ini yang dipakai oleh peneliti adalah perpanjang pengamatan, meningkatkan ketekunan, dan triangulasi. Hasil penelitian menunjukan bahwa Pegadaian Syari ah Unit Kampung Solok Muara Bungo telah melaksanakan
\end{abstract}


Rena, Ainil : Penerapan Nilai-Nilai Syariah...

semua nilai-nilai syari’ah maupun nilai-nilai dari Pegadaian itu sendiri. Hanya saja belum sempurna karena masih ada yang belum terlaksana dengan baik yaitu memanfaatkan teknologi dengan baik dan belum menjalankan do'a pagi setiap hari.

Kata Kunci: Nilai-Nilai Syariah, Pegadaian Syariah

\section{A. Pendahuluan}

Lembaga Pegadaian di Indonesia sudah lama berdiri sejak masa kolonial Belanda pada tahun 1746. Untuk menekan praktek Pegadaian ilegal serta memperkecil lintah darat yang sangat merugikan masyarakat, maka Pemerintah Kolonial Belanda memonopoli usaha Pegadaian dengan mendirikan Jawatan Pegadaian yang berada dalam lingkungan Kantor Besar Keuangan. Sejarah pegadaian dimulai saat VOC mendirikan Bank Van Leening sebagai lembaga keuangan yang memberikan kredit dengan sistem gadai. Pada tahun 1811 pemerintahan Inggris mengambil alih dan membubarkan Bank Van Leening dan masyarakat di beri kekuasaan mendirikan usaha pergadaian. Tepatnya pada tanggal 1 April tahun1901 pegadaian pertama kali didirikan di Indonesia yaitu di Sukabumi Jawa Barat. Tahun 1905 pegadaian berubah berbentuk menjadi lembaga resmi yaitu Jawatan. Tahun 1961 bentuk badan hukum Jawatan berubah menjadi Perusahaan Negara (PN) berdasarkan peraturan pemerintah pengganti Undang-Undang (Perpu) No. 19 tahun 1960 tentang peraturan pemerintah (PP) No. 178 tahun 1961. Selanjutnya bentuk badan hukum berubah dari Perusahaan Negara (PN) menjadi Perusahaan Jawatan (PERJAN) berdasarkan peraturan pemerintah No. 7 tahun 1969. Pada tahun 1990 bentuk badan hukum berubah dari Perusahaan Jawatan (PERJAN) menjadi Perusahaan Umum (PERUM) berdasarkan peraturan pemerintah (PP) No. 10 tahun 1990 yang diperbaharui dengan peraturan pemerintah (PP) No. 103 tahun 2000. Pada tahun 2012 bentuk badan hukum berubah dari Perusahaan Umum (PERUM) menjadi Perusahaan Seorang (PERSERO) pada tanggal 1 April 2012 berdasarkan peraturan pemerintah (PP) No. 51 tahun 2011.

\section{B. LandasanTeori}

Di dalam hukum Islam permasalahan mu`amalah terutama dalam mengadaikan suatu barang yang pertama telah tercantum di dalam Al-Qur`an Surah AlBaqarah ayat 283 :

Artinya: "Jika kamu dalam perjalanan (dan bermu'amalah tidak secara tunai) sedang kamu tidak memperoleh seorang penulis, maka hendaklah ada barang 
Rena, Ainil : Penerapan Nilai-Nilai Syariah...

tanggungan yang dipegang (oleh yang berpiutang). Akan tetapi jika sebagian kamu mempercayai sebagian yang lain, maka hendaklah yang dipercayai itu menunaikan amanatnya (hutangnya) dan hendaklah ia bertakwa kepada Allah Tuhannya, dan janganlah kamu (para saksi) menyembunyikan persaksian. Dan Barangsiapa yang menyembunyikannya, maka sesungguhnya ia adalah orang yang berdosa hatinya, dan Allah Maha mengetahui apa yang kamu kerjakan".

Dasar hukum yang kedua untuk dijadikan rujukan dalam membuat rumusan gadai syariah adalah Hadist Bukhari Nomor 2211, sebagai berikut :

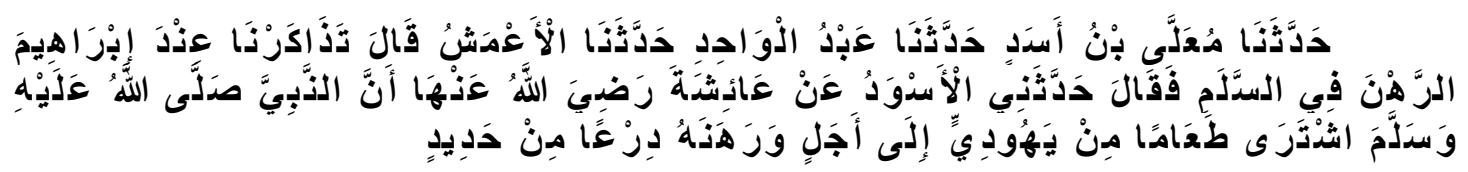

Artinya: "Telah menceritakan kepada kami [Mu'allaa bin Asad] telah menceritakan kepada kami ['Abdul Wahid] telah menceritakan kepada kami [Al A'masy] berkata; "Kami pernah saling menceritakan dihadapan [Ibrahim] tentang gadai dalam jual beli As Salam, maka dia berkata, telah menceritakan kepadaku [Al Aswad] dari ['Aisyah Radliallahu 'anha] bahwa Nabi Shallallahu 'Alaihi Wasallam pernah membeli makanan dari orang Yahudi (yang pembayaranya) di masa yang akan datang lalu Beliau menggadaikan baju besi Beliau (sebagai jaminan) ".

Fatwa Dewan Syariah Nasional Majelis Ulama Indonesia (DSN-MUI) menjadi salah satu rujukan yang berkenaan dengan Gadai Syariah, di antaranya dikemukakan sebagai berkut: Fatwa Dewan Syariah Nasional Majelis Ulama Indonesia No. 25/DSNMUI/III/2002, tentang Rahn dan Fatwa Dewan Syariah Nasional Majelis Ulama Indonesia No: 43/DSN-MUI/VIII/2004 tentang Ganti Rugi.

Peneliti telah melakukan pengamatan awal pada waktu Praktik Kerja Lapangan di Kantor Unit Pegadaian Syariah Kampung Solok Muara Bungo selama 2 Bulan terhitung mulai tanggal 06 Agustus 1918 sampai dengan 06 Oktober 2018 dan peneliti melihat kurangnya penerapan nilai-nilai syariah di dalam kinerja sehari-hari.

Peneliti menemukan kekurangan dalam menerapkan nilai-nilai syariah yaitu, kurangnya keramahan dalam bentuk pelayanan pada nasabah, pada saat nasabah hendak melakukan transaksi di Kantor Unit Pegadaian Syariah karyawan Pegadaian Syariah kurangnya menunjukan keramahan dalam bentuk pelayanan kepada nasabah. Hal ini membuat nasabah kurang nyaman dalam melakukan transaksi di Pegadaian Syariah tersebut. Didalam agama Islam masalah keramahan merupakan masalah yang sangat penting untuk di perhatikan baik didalam kehidupan sehari maupun dalam bekerja, Allah berfirman dalam Qur`an Surah Ali Imran: 159. 


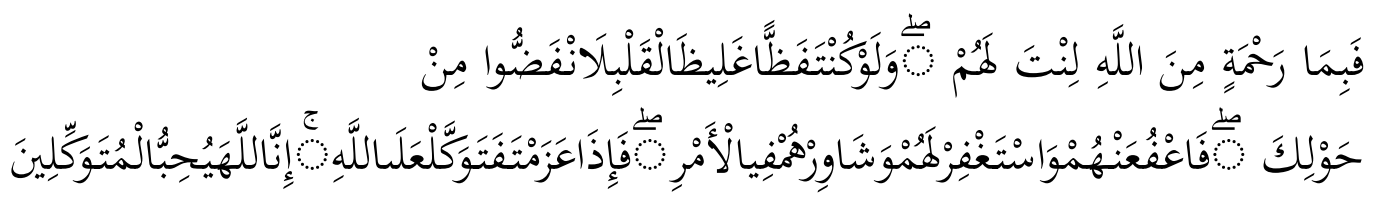

Artinya: "Maka disebabkan Rahmat dari Allah-lah kamu berlaku lemah lembut terhadap mereka. Sekiranya kamu bersikap keras lagi berhati kasar, tentulah mereka menjauhkan diri dari sekelilingmu. Karena itu ma'afkanlah mereka, mohonkanlah ampun bagi mereka, dan bermusyawaratlah dengan mereka dalam urusan itu, kemudian apabila kamu telah membulatkan tekad, Maka bertawakkallah kepada Allah. Sesungguhnya Allah menyukai orang-orang yang bertawakkal kepada-Nya."

Transaksi hukum gadai dalam fikih Islam disebut ar-rahn. Ar-rahn adalah suatu jenis perjanjian untuk menahan suatu barang sebagai tanggungan utang. Pergertian arrahn dalam bahasa Arab adalah ats-tsubut wa ad-dawam yang berarti "tetap" dan "kekal", seperti dalam kalimat maun rahin yang berarti air yang tenang. Hal itu berdasarkan firman Allah SWT dalam QS. Al-Muddatstsir (74) ayat 38 Artinya: "Tiaptiap diri bertanggung jawab atas apa yang telah diperbuatnya".

Ruang lingkup pemasaran Pegadaian Syariah meliputi nasabah dari berbagai golongan maupun tingkat sosial ekonomi masyarakat mulai dari golongan ekonomi lemah, menengah hingga kalangan atas. Pegadaian tidak membeda - bedakan nasabah dalam pelayanan transaksi agar tidak terjadi kecemburuan sosial. Untuk dapat melakukan transaksi di pegadaian terlebih dahulu calon nasabah harus mendaftarkan diri menjadi member pada pegadaian. Setelah itu nasabah dapat menikmati segala fasilitas produk dan jasa yang ditawarkan oleh pegadaian. ${ }^{3}$

Di dalam Islam Nilai-Nilai Syariah bukan hanya terdapat di pendidikan, kehidupan sehari-hari saja, namun juga harus di terapkan di tempat-tempat kerja seperti perkantoran di setiap pekerjaan yang kita lakukan sejenis Pegadaian maupun yang lainnya. Nilai-Nilai Syariah ini perlu di terapkan kepada karyawan-karyawan diantaranya ketika bekerja niat utamanya adalah karena Allah SWT. Kita sadar bahwa bekerja adalah kewajiban dari Allah SWT yang harus di lakukan oleh setiap hamba-Nya, serta mengetahui bahwa hanya dengan bekerjalah kita dapat menunaikan kewajibankewajiban Islam yang lainya, contohnya seperti zakat, infaq dan sedekah. Seorang karyawan juga harus sadar bahwa kehadiran tepat waktunya, menyelesaikan apa yang sudah menjadi kewajibannya secara tuntas, tidak menunda-nunda suatu pekerjaan,

${ }^{3}$ www. Pegadaian. Co. id 
Rena, Ainil : Penerapan Nilai-Nilai Syariah...

tidak mengabaikan pekerjaannya adalah bagian yang tidak terpisahkan dari komponen bekerja itu sendiri yang merupakan ibadah kepada Allah SWT. ${ }^{4}$

Hakikatnya pekerjaan yang kita lakukan tersebut merupakan amanah, baik secara duniawi dari atasan, maupun secara akherati dari Allah SWT yang nantinya di mintai pertanggungjawaban atas pekerjaan yang di lakukannya. Dalam bekerja juga harus memperhatikan adab serta etika sebagai seorang muslim, seperti etika ketika berbicara, menegur, berpakaian, berhadapan dengan customer, rapat dan lainnya. Bahkan etika/akhlak ini merupakan ciri kesempurnaan iman seorang muslim.

Salah satu sumber yang menjadi rujukan dari nilai-nilai syariah dan penerapannya pada Pegadaian Syariah adalah nilai-nilai syariah yang bersumber dari Nabi Muhammad SAW, yaitu sebagai berikut: ${ }^{5}$

1. Kejujuran

Dalam setiap transaksi penerapan harus lebih mengutamakan kejujuran dan memegang teguh kepercayaan yang diberikan oleh nasabah, dalam setiap penyampaian selalu berkata benar dan jelas. Selain itu, dalam setiap transaksi penerapan harus bersikap sopan dan bertingkah laku baik.Seperti yang disinggung diatas bahwa nilai-nilai terpenting sebagai landasan terpenting transaksi dalam Pegadaian Syariah adalah kejujuran. Hal itu merupakan puncak dari moralitas iman dan karakteristik yang paling menonjol dari orang-orang yang beriman, tanpa kejujuran kehidupan yang agamis tidak akan berdiri tegak dan kehidupan didunia tidak berjalan aman.

Kejujuran dalam bekerja yang di maksud adalah konsistensi pada tujuan perusahaan serta karyawan di tuntut untuk memenuhi kode etik yang telah di sediakan oleh perusahaan. Dari sikap kejujuran demikian maka suatu bisnis secara otomatis akan melahirkan persaudaraan dan kemitraan yang saling menguntungkan, tanpa adanya kerugian dan penyesalan nantinya.

Nilai kejujuran ini di dasarkan pada Firman Allah SWT dalam Al-Qur`an surah Al-maidah ayat 8.

Artinya: "Hai orang-orang yang beriman hendaklah kamu jadi orang-orang yang selalu menegakkan (kebenaran) karena Allah, menjadi saksi dengan adil, dan

\footnotetext{
${ }^{4}$ Ibid

${ }^{5}$ Ema Salma, Nilai-Nilai Islam Pada Bank Berbasis Syariah, Skripsi, Fakultas Dakwah Dan Komunikasi UIN Alauddin Makasar, 2017.
} 
Rena, Ainil : Penerapan Nilai-Nilai Syariah...

janganlah sekali-kali kebencianmu terhadap sesuatu kaum, mendorong kamu untuk berlaku tidak adil. Berlaku adillah, karena adil itu lebih dekat kepada takwa. Dan bertakwalah kepada Allah, Sesungguhnya Allah Maha mengetahui apa yang kamu kerjakan."6

\section{Bertanggung jawab}

Dalam pengertian kontekstualnya, bertanggung jawab kita fahami sebagai sebuah kepercayaan yang diemban manusia baik dalam membangun konfigurasi relasi yang baik dengan sesama manusia, dengan lingkungan alamnya dan relasinya dengan Tuhan. Rasa tanggungjawab ini sangat penting pada saat nasabah melakukan transaksi. Dalam hal ini para Insan Pegadaian Syariah haruslah benar-benar bertanggungjawab dalam menjaga janji dan kepercayaan nasabah dalam menitipkan barang atau dalam hal lainnya.

Tanggungjawab merupakan faktor utama terciptanya kesejahteraan dan kemakuran sebuah Pegadaian Syariah, sebab dengan sikap tanggung jawab yang dimiliki oleh para Insan Pegadaian Syariah semua komponen Pegadaian Syariah akan berlaku jujur, adli, disiplin, bertanggungjawab dalam setiap operasionalnya.

Allah SWT berfirman tentang di dalam Q.S Al-Muthaffifin ayat 1.

Artinya: "Kecelakaan besarlah bagi orang-orang yang curang".

Dan juga bertanggungjawab ini sama halnya dengan amanah. Di jelaskan dalam firman Allah SWT dalam Qur`an Surah An-Nissa`ayat 58.

Artinya: "Sesungguhnya Allah menyuruh kamu menyampaikan amanat kepada yang berhak menerimanya, dan (menyuruh kamu) apabila menetapkan hukum di antara manusia supaya kamu menetapkan dengan adil. Sesungguhnya Allah memberi pengajaran yang sebaik-baiknya kepadamu. Sesungguhnya Allah adalah Maha mendengar lagi Maha melihat".7

\section{Transparansi}

Nilai transparansi yang dimaksudkan adalah menjelaskan kepada nasabah apa adanya tanpa ada yang di tutupi dari nasabah berupa penyampaian informasi apa saja yang harus di ketahui oleh nasabah mengenai suatu produk.

${ }^{6}$ Kementerian Agama RI, Al-Quran dan Terjemahannya (Jakarta: PT Sinergi Pustaka Indonesia, 2012)

${ }^{7}$ Kementerian Agama RI, Al-Qur`an dan Terjemahannya (Jakarta: PT Sinergi Pustaka Indonesia, 2012) 
Rena, Ainil : Penerapan Nilai-Nilai Syariah...

Informasi yang harus diketahui nasabah pada produk tidak hanya pada saat nasabah telah memilih untuk membeli atau mengikuti salah satu produknya tetapi penyampaian informasi yang transparan harus secara jelas disampaikan terlebih dahulu oleh staf Pegadaian Syariah sebelum dilakukanya persetujuan pembelian atau keikutsertaan nasabah atas suatu produk.

Jadi dapat disimpulkan bahwa yang dimaksud dngan nilai transparansi adalah informasi sehubungan dengan produk pendanaan Pegadaian Syariah yaitu penyampaian keterangan atau penerangan / pemberitahuan yang mengandung nilai, makna dan pesan baik fakta maupun penjelasanya yang dapat dilihat, didengar dan dibaca yang disajikan dengan perkembangan teknologi informasi dan komunikasi secara elektronik atau non -elektronik mengenai karakteristik produk pendanaan Pegadaian Syariah.

Allah telah menjelaskan dalam Q.S Al-Hijr ayat 94 tentang menyapaikan tentang sesuatu secara terang-terangan atau transparansi.

Artinya: "Maka sampaikanlah olehmu secara terang-terangan segala apa yang diperintahkan (kepadamu) dan berpalinglah dari orang-orang yang musyrik".8

\section{Komunikatif 9}

Sesungguhnya dalam setiap gerak manusia tidak dapat menghindari untuk berkomunikasi. Dalam Pegadaian Syariah komunikasi menjadi faktor penting dalam melakukan transformasi kebijakan atau keputusan dalam rangka pelaksanaan manajerial itu sendiri menuju tercapainya tujuan yang di harapkan. Begitu pentingnya komunikasi di dalam Pegadaian Syariah sehingga manusia perlu berkomunikasi untuk menghindari miskomunikasi.

Ketepatan penyampaian komunikasi ini, selanjutnya disebut sebagai komunikatif. Berkaitan dengan komunikatif ini, Al-Qur`an memberikan penjelasan dalam Q.S Thaha ayat 44:

Artinya: "Maka berbicaralah kamu berdua kepadanya dengan kata-kata yang lemah lembut, Mudah-mudahan ia ingat atau takut".10

\footnotetext{
${ }^{8}$ Kementerian Agama RI, Al-Qur`an dan Terjemahannya (Jakarta: PT Sinergi Pustaka Indonesia, 2012)

${ }^{9}$ Pola Manajemen Bank Syariah Di Download Pada Http://www.slidershare.net
} 
Rena, Ainil : Penerapan Nilai-Nilai Syariah...

Selain nilai-nilai syariah Pegadaian Syariah Unit Kampung Solok Muara Bungo juga menerapkan nilai-nilai internal dari Pegadaian itu sendiri. Nilai-nilai internal tersebut adalah G-Values yaitu, Integrity, Professional,Mutual trust, Customer Focus, dan Sosial Value.

1. Integrity, yaitu memiliki prinsip moral yang kuat, jujur, tulus, objektif, serta dapat keseseuaian antara pikiran, ucapan dan tindakan. Misalnya, bekerja dengan ikhlas sepenuh hati untuk kepentingan perusahaan bukan untuk kepentingan pribadi.

2. Professional, selalu mengembangkan diri dan meningkatkan keahlian dengan komitmen tinggi untuk melakukan pekerjaan secara efektif dan efisien. Misalnya, tanpa menunggu arahan berinisiatif untuk memperbaiki keadaan dan cepat menyesuaikan dengan perusahaan eksternal dan internal untuk mengambil tindakan atau keputusan.

3. Mutual trust, menciptakan keyakinan bersama secara terbuka, transparan, kolaboratif, dan tidak sungkan serta memelihara budaya saling menghargai diantara karyawan untuk mencapai tujuan perusahaan. Misalnya, bersedia menerima masukan, kritikan dan saran dari rekan kerja mapun atasan.

4. Customer Focus, memberikan layanan terbaik kepada pelanggan (internal dan eksternal) dan menjadikan kebutuhan serta harapan pelanggan sebagai fokus utama. Misalnya, memberikan pelayanan terbaik kepada pelanggan melebihi yang diharapkan.

5. Sosial Value, bertindak berlandakan manfaat untuk peduli dan memberi nilai tambah bagi lingkungan serta nama baik perusahaan. Misalnya, dalam bekerja selalu mempertimbangkan dampak dan manfaatnya bagi lingkungan maupun masyarakat sekitar.

Semua nilai-nilai G-Values ini terdapat didalam 10 perilaku utama Insan Pegadaian yaitu:

a. Senantiasa bersikap jujur, tulus, dan objektif.

b. Bersikap konsisten antara pikiran, ucapan dan tindakan.

${ }^{10}$ Kementerian Agama RI, Al-Qur`an dan Terjemahannya (Jakarta: PT Sinergi Pustaka Indonesia, 
Rena, Ainil : Penerapan Nilai-Nilai Syariah...

c. Senantiasa memiliki inisiatif, gesit dalam meyesuaikan perubahan kondisi untuk penyempurnaan dan inovasi dengan memanfaatkan tekhnologi terkini.

d. Memiliki jiwa entrepreneurship dan global mindset dalam mengambil keputusan bisnis.

e. Menyelesaikan tugas dengan hasil terbaik penuh komitmen, serta tetap dalam koridor aturan yang berlaku.

f. Menciptakan keyakinan bersama, terbuka dan transparan dalam mencapai tujuan perusahaan.

g. Mengutamakan semangat kolaboratif untuk sinergi dan saling menghargai antar karyawan.

h. Tidak sungkan memberikan atau menerima masukan dan kritik.

i. Fokus pada pelayanan bagi pelanggan untuk memberikan solusi terbaik melebihi kebutuhan dan harapan pelanggan.

j. Peduli dan memberikan manfaat kepada lingkungan serta nama baik perusahaan.

Berikut ini adalah beberapa kajian yang berkaitan dengan Penerapan Nilai-Nilai Syariah antara lain sebagai berikut:

1) Andi Muhammad Nurul Afdal, penelitian ini merupakan skripsi dengan judul "Studi Pemahaman Nilai-Nilai Syariah Pada Praktisi Perbankan Syariah" yang dilakukan di PT. Bank Perkreditan Rakyat Syariah Niaga Mandiri. Metodologi yang digunakan adalah kualitatif. Hasil penelitian ini menunjukan bahwa di tinjau dari pemahaman teori dan praktik bahwa Akuntansi Syariah bersifat manusiawi dan instrumennya dapat di praktikan dalam dunia nyata, berdasarkan prinsip-prinsip syariah yang humanis. ${ }^{11}$

2) Hania Husna, penelitian ini merupakan skripsi dengan judul " Pengaruh Penerapan Nilai-Nilai Islam Pada Bank BNI Syariah Banda Aceh Terhadap Semangat Kerja karyawan" metodologi yang digunakan merupakan kuantitatif. Hasil penelitian ini menunjukan bahwa tingkat penerapan nilainilai Islam pada karyawan Bank BNI sudah bagus akan penerapannya. Dan

\footnotetext{
${ }^{11}$ Andi Muhammad Nurul Afdal "Studi Pemahaman Nilai-Nilai Syariah Pada Praktisi Perbankan Syariah" (studi kasus PT. Bank Perkreditan Rakyat Syariah Niaga Madani), Skripsi, Universitas Hasanuddin 2011, h. 96.
} 
Rena, Ainil : Penerapan Nilai-Nilai Syariah...

fokus pada pelanggan merupakan hal yang paling berpengaruh terhadap semangat karyawan. ${ }^{12}$

3) Ema Salma, penelitian ini merupakan penelitian skripsi dengan judul " NilaiNilai Islam Pada Bank Berbasis Syariah". Di lakukan di BNI Syariah Cabang Kota Makasar. Metodologi yang digunakan adalah kualitatif. Hasil pada penelitian ini menggunakan prinsip syariah dan POAC, yaitu; Planning (Perencanaan), Organizing (Pengorganisasian), Actuating (Pelaksanaan), dan Controling (Pengawasan). Hal ini dilakukan untuk memenuhi kebutuhan masyarakat secara menyeluruh baik itu dari segi peningkatan usahanya maupun bagi masyarakat yang ingin membangun usahanya, selain itu untuk mengembangkan BNI Syariah Cabang Kota Makassar. ${ }^{13}$

Dari penelitian yang relevan diatas maka dapat disimpulkan bahwa, pada setiap Lembaga Keuangan Syariah seharusnya menjalankan nilai-nilai syariah yang telah dibuat oleh perusahaan masing-masing. Baik itu berberntuk perbankan maupun non-bank seperti Pegadaian Syariah.

Analisis data dalam penelitian kualitatif, dilakukan pada saat pengumpulan data berlangsung, dan setelah selesai pengumpulan data dalam periode tertentu. Pada saat wawancara, peneliti sudah melakukan analisis terhadap jawaban yang diwawancarai. Bila jawaban yang diwawancarai setelah dianalisis terasa belum memuaskan, maka peneliti akan melanjutkan pertanyaan lagi, sampai tahap tertentu, diperoleh data yang dianggap kredibel. Miles dan Huberman, mengemukakan bahwa aktivitas dalam analisis dalam kualitatif dilakukan secara interaktif dan berlangsung secara terus-menurus sampai tuntas, sehingga datanya sudah jenuh. Aktivitas dalam analisis data, yaitu data reduction, data display, dan conclusion drawing/verification. ${ }^{14}$

Kesimpulan dalam penelitian kualitatif merupakan temuan baru yang sebelumnya belum pernah ada. Temuan dapat berupa deskripsi atau gambaran suatu objek yang sebelumnya masih dapat berupa hubungan kausal atau interaktif, hipotesis atau teori.

\footnotetext{
${ }^{12}$ Hania Husna, "Pengaruh Penerapan Nilai-Nilai Islam Pada Bank BNI Syariah Banda Aceh TerhadapSemangat Kerja Karyawan”, Skripsi Universitas Islam Negeri Ar-Raniry Banda Aceh, Program Studi Perbankan Syariah Fakultas Ekonomi Islam Dan Bisni Islam, 2018. h. 90

${ }^{13}$ Ema Salma, "Nilai-Nilai Islam Pada BankBerbasis Syariah (studi kasus pada BNI Syariah Cabang Kota Makasar)", Skripsi UIN Alauddin Makasar, Fakultas Dakwah dan Komunikasi, 2017. h, 102

${ }^{14}$ Sugiyono,Memahami Penelitian Kualitatif, (Bandung: Alfabeta, 2007), cet. 3. h. 91
} 
Rena, Ainil : Penerapan Nilai-Nilai Syariah...

\section{Hasil Penelitian}

1. Nilai-Nilai Syariah Pada Pegadaian Syariah Unit Kampung Solok Muara Bungo.

Untuk mengetahui nilai-nilai syariah di Pegadaian Syariah Unit Kampung Solok Muara Bungo maka peneliti melakukan observasi, wawancara serta menelaah dokumentasi-dokumentasi yang ada di Kantor Pegadaian Syariah Unit Kampung Solok Muara Bungo. Berdasarkan observasi maka dapat di ketahui bahwa nilai-nilai syariah yang terdapat di Pegadaian Syariah Unit Kampung Solok Muara Bungo, adalah sebagai berikut :

a. Kejujuran, berdasarkan observasi Pegadaian Syariah Unit Kampung Solok Muara Bungo memiliki nilai-nilai syariah seperti nilai kejujuran. Nilai kejujuran ini dapat dibuktikan di Pegadaian Syariah Unit Kampung Solok Muara Bungo dengan cara melihat laporan yang mereka buatkan, dan hubungan insan pegadaian dengan nasabah yang melakukan transaksi di Pegadaian Syariah Unit Kampung Solok Muara Bungo ${ }^{15}$. Hasil obervasi ini juga di perkuat dengan hasil wawancara dengan Pengelola Kantor Unit Pegadaian Syariah Kampung Solok Muara Bungo sebagai berikut:

"Alhamdulillah kami masih bisa menanamkan nilai kejujuran dan menjalankannya dengan baik pada kantor ini dan juga pada nasabah. Alhasil nasabah yang datang sangat mempercayai kami dan nasabah kami menjadi bertambah karena kepercayaannya kepada kami, salah satu contoh dari penerapan nilai kejujuran ini kami terapkan adalah kemarin itu ada uang pembayaran nasabah yang lebih lalu kami kembalikan, bisa saja uang itu kami ambil tapi kami takut nasabah sengaja melebihkan uang tersebut untuk melihat kejujuran kami. Namun bukan hanya itu pegadaian ini dibangun untuk membantu masyarakat bukan untuk membuat masyarakat lebih susah".16

Selain melakukan wawancara dengan pengelola Pegadaian Syariah peeneliti juga melakukan wawancara dengan nasabah yang telah bertransaksi di Pegadaian Syariah Unit Kampung Solok sebagai berikut :

"Menurut saya dalam nilai kejujuran ini mereka sudah jujur. Saya bilang begini karena mereka benar-benar menjelaskan kepada saya tentang transaksi yang saya kerjakan disini. Contohnya, saya sedang melakukan transaksi pembayaran angsuran Arrum Haji dan selama ini ketika saya melakukan pembayaran mereka selalu menjelaskan kepada saya tanggal saya melakukan

\footnotetext{
${ }^{15}$ Observasi tanggal 16 September 2019.

${ }^{16}$ Tomi Dian Utama, ST,. M.HI, Pengelola Kantor Unit Pegadaian Syariah Kampung Solok Muara Bungo, Wawancara tanggal 16 September 2019.
} 
Rena, Ainil : Penerapan Nilai-Nilai Syariah...

transaksi hari ini, pembayaran bulan keberapa dan banyak lagi yang mereka jelaskan." 17

b. Bertanggungjawab, berdasarkan observasi Pegadaian Syariah juga menerapkan nilai syariah yaitu bertanggungjawab. Nilai ini sangat di butuhkan dalam setiap perusahaan, bukan hanya Pegadaian Syariah namun juga Insan Pegadaian Syariah harus mempunyai nilai bertanggung jawab dalam dirinya. Hasil observasi ini diperkuat dengan hasil wawancara dengan Pengelola Pegadaian Syariah :

"Menjaga barang milik nasabah merupakan tanggungjawab kami. Dan kami haruslah menjaganya dengan baik sampai nasabah mengambil barang miliknya kembali. Kami menjaga milik nasabah agar nasabah tetap mempercayai kami, misalnya adalah melakukan pekerjaan dengan benar, terbuka apa adanya dan bekerja sesuai ketentuan yang berlaku".18

Selain itu, peneliti juga melakukan wawancara dengan Nasabah Pegadaian Syariah Unit Kampung Solok Muara Bungo, sebagai berikut:

"Mereka benar-benar menjaga barang yang telah saya titipkan disini selama saya menggadaikan. Dan sampai saya menebus barang ini kembali, semuanya masih utuh tanpa kurang satupun".

c. Transparansi, berdasarkan observasi maka terdapat nilai transparansi di Pegadaian Syariah Unit Kampung Solok Muara Bungo yaitu ketika insan pegadaian syariah menjelaskan apa adanya kepada nasabah atau dapat dilihat melalui daftar harga dapat di cantumkan dalam bentuk brosur. Hasil Selain observasi peneliti juga mewawancarai beberapa pihak terkait tentang nilainilai syariah di Pegadaian Syariah Unit Kampung Solok Muara Bungo :

“ Menurut saya transparansi itu membuka diri kepada nasabah tentang Pegadaian Syariah Unit Kampung Solok ini. Ya benar kami menerapkan nilai transparansi ini agar nasabah tetap memparcayai kami dan perusahaan dengan apa yang kami bicarakan, salah satu contohnya adalah ketika nasabah menanyakan tentang Arrum haji kepada kami dan kami jelaskan seperti yang terdapat pada brosur yang telah dicetak dari perusahaan". ${ }^{19}$

Hal ini di benarkan oleh salah seorang sekurity Pegadaian Syariah:

"Ketika kami menjelaskan kepada Nasabah kami juga memegang atau membawa brosur produk yang ditanyakan. Jadi ketika nasabah bertanya tentang

\footnotetext{
${ }^{17}$ Asri Wahyuni, Angsuran Arrum Haji, Wawancara tanggal 22 Oktober 2019 di Pegadaian Syariah Unit Kampung Solok Muara Bungo.

${ }^{18}$ Tomi

${ }^{19}$ Ibid, tanggal 17 September 2019
} 
Rena, Ainil : Penerapan Nilai-Nilai Syariah...

yang kami jelaskan, kami bisa menunjukan buktinya bahwa apa yang kami jelaskan telah sesuai seperti yang terdapat di brosur".20

Selain itu peneliti juga mewawancarai nasabah sebagai berikut:

"Sebelum saya menggadaikan dulu, saya datang untuk bertanya-tanya tetntang bagaimana proses dan segala macam persyaratannya. Dan orang pegadaian menjelaskan kepada saya semuanya, bahkan mereka memberikan saya brosur tentang apa yang hendak saya lakukan. Dan akhirnya saya percaya dengan apa yang mereka katakan dan mereka juga sudah menunjukan apa yang mereka ucapkan itu benar makanya saya jadi menggadaikan disini."

d. Komunikatif, berdasarkan observasi berkomunikasi yang baik dengan nasabah merupakan awalan yang baik. Jika berkomunikasi baik dengan nasabah, maka nasabah akan senang dengan Insan Pegadaian Syariah dan juga senang melakukan transaksi yang dilakukan nasabah, serta tidak membosankan bagi nasabah jika sedang melakukan transaksi. Berkomunikasi ini tidak hanya ketika sedang melakukan transaksi namun juga kepada siapa saja yang datang ke Pegadaian Syariah, baik itu Nasabah maupun yang bukan Nasabah. Berkomunikasi dengan baiktidakhanya diterapkan di dalam pekerjaan, namun juga didalam kehidupan sehari-hari. Hasil observasi ini juga di perkuat dengan hasil wawancara dengan Pengelola Pegadaian Syariah:

"Memang sudah seharusnya berkomunikasi dengan baik kepada siapa saja, apalagi kepada nasabah yang hendak melakukan transaksi atau bertanya-tanya di Pegadaian Syariah ini. Jika kami tidak berkomunikasi dengan baik maka nasabah akan enggan melakukan transaksi disini dan para nasabah akan sungkan untuk datang kesini dilain waktu, berkomunikasi dengan baik juga diajarkan oleh agama kepada siapapun, contohnya adalah menjelaskan kepada nasabah tentang transaksi yang dilakukannya.".21

Hal ini juga di benarkan oleh sekurity Pegadaian Syariah :

"Ketika nasabah sedang menunggu dalam proses transaksi kami mengajak nasabah untuk berbicara, seperti menawarkan nasabah produk-produk yang lain, dan nasabah bertanya apa yang membuatnya tidak paham tentang Pegadaian Syariah ini" ${ }^{22}$

\footnotetext{
${ }^{20}$ Yogi Pranata, Sekurity Pegadaian Syariah Unit Kampung Solok Muara Bungo, Wawancara tanggal 17 September 2019.

${ }^{21}$ Ibid, tanggal 18 September 2019

${ }^{22}$ Eri Subagia, Sekurity Pegadaian Syariah Unit Kampung Solok Muara Bungo, Wawancara tanggal 18 September 2019
} 
Rena, Ainil : Penerapan Nilai-Nilai Syariah...

Selain itu peneliti juga mewawancarai nasabah terkait tentang hal komunikasi sebagai berikut:

" Saya pikir mereka lumayan ramah kepada setiap orang yang datang ke pegadaian. Mereka sering kali mengajak kami berbicara selama kami menunggu tidak hanya membicarakan tentang pegadaian namun bisa juga hal-hal lainya."

Selain nilai-nilai syariah Pegadaian Syariah Unit Kampung Solok juga menerapkan beberapa nilai-nilai syariah secara sederhana setiap harinya, yaitu :

1) Do`a pagi : Sebelum memulai kegiatan di pagi hari seluruh Insan Pegadaian Syariah Unit Kampung Solok Muara Bungo melakukan do`a pagi bersama.

2) Yel-yel : Setelah melakukan do`a pagi Insan Pegadaian Syariah Unit Kampung Solok Muara Bungo membacakan yel-yel yang dibuatkan untuk menambah semangat dan kekompakan sesama Insan Pegadaian Syariah Unit Kampung Solok Muara Bungo.

Penerapan nilai-nilai syariah diatas dapat berjalan dengan baik di Pegadaian Syariah Unit Kampung Solok Muara Bungo, namun masih terdapat beberapa faktor permasalahan, yaitu:

a. Keterbatasan sumber daya manusia, Pegadaian Syariah Unit Kampung Solok Muara Bungo memiliki masalah yaitu keterbatasan sumber daya manusia, dalam hal ini pengelola pegadaian syariah sangat harus melakukan pekerjaan rangkap untuk tercapainya semua tugas, misalnya pengelola Pegadaian Syariah Unit Kampung Solok Muara Bungo harus meragkap kerja menjadi penaksir. Kasir yang merangkap kerja menjadi marketing bersamaan dengan sekuriti.

Setelah melakukan observasi, peneliti juga melakukan wawancara denganpengelola Pegadaian Syariah:

"Sebenarnyakantor ini mengalami kekurangan Sumber Daya Manusia pada bidang-bidang tertentu sehingga terjadilah yang namanya rangkap kerja. Namun sebenarnya walaupun kami kekurangan SDM kami juga tidak bisa menambah sumber daya baru karena disini letaknya adalah unit. Di unit biasanya memang dihuni oleh sedikit orang dan terpaksa melakukan rangkap kerja. Dimanapun yang namanya unit tetap memiliki sumber daya yang terbatas".23

b. Belum memanfaatkan tekhnologi dengan baik, Pegadaian Syariah Unit Kampung Solok Muara Bungo memiliki karyawan yang di anggap sudah

\footnotetext{
${ }^{23}$ Tomi, Wawancara tanggal 22 Oktober 2019
} 
Rena, Ainil : Penerapan Nilai-Nilai Syariah...

memiliki batas usia senior untuk menjalankan pekerjaan, dalam hal ini pekerjaan menjadi sulit karena kurang mengertinya dengan sistem teknologi.

Setelah melakukan observasi, peneliti jugadiperkuat dengan hasil wawancara dengan pengelola Pegadaian Syariah:

"Dizaman yang modern ini setiap pekerjaan melaksanakan sistem teknologi. Termasuklah dengan Pegadaian Syariah ini. Sebenarnya dari Kantor Pusat juga telah menggunakan sistem teknologi, namun letak permasalahannnya disini adalah sumber dayanya yang kurang baik ataupun kurang lancar menggunakan teknologi ini atau biasanya kita menyebutnya dengan kurang memanfaatkan teknologi. Padahal sebenarnya jika sumber daya ini menggunakan atau memanfaatkan teknologi ini sebenarnya bisa meringankan beban pekerjaannya sendiri" ${ }^{24}$

c. Do`a pagi yang belum berjalan dengan baik, pegadaian syariah unit kampung solok muara bungo setiap pagi selalu melaksanakan do`a pagi. Namun kadang tidak berjalan dengan baik karena kadang tidakdapat dijalankan setiap hari. Dengan alasan kadang nasabah duluan datang sebelum melaksanakan doa pagi jadinya tidak di laksanakan dan juga kadang datang kesiangan jadi tidak dilakukan do`a pagi tersebut.

Dari uraian yang telah dipaparkan, maka dapat disimpulkanbahwa nilai-nilai syariah yang ada dan di implementasikan di Pegadaian Syariah Unit Kampung Solok Muara Bungo adalah :
a. Kejujuran.
b. Bertanggungjawab.
c. Transparansi.
d. Komunikatif.

Penerapan nilai-nilai syariah di Pegadaian Syariah Unit Kampung Solok Muara Bungo telah diterapkan dengan baik. Namun, walaupun telah diterapkan dengan baik masih terdapat beberapa permasalahan didalamnya diantaranya :
a. Kekurangan Sumber Daya Manusia (SDM).
b. Kurang memanfaatkan tekhnologi dengan baik.
c. Do`a pagi yang belum dijalankan setiap hari. 
Rena, Ainil : Penerapan Nilai-Nilai Syariah...

\section{DAFTAR PUSTAKA}

Al-Qur`an dan Terjemahannya. Kementerian Agama RI. Jakarta:PT Sinergi Pustaka Indonesia. 2012

Afid Burhanuddin. Penelitian Kuantitatif dan Kualitatif. diambil di www. Google.com, 2014.

Ahmad Wardi muslich. Fiqh Muamalat. Jakarta: Siniar Grafika 2010. cet. 1

Andi Muhammad Nurul Afdal, "Studi Pemahaman Nilai-Nilai Syariah Pada Praktisi Syariah", (Thesis, Universitas Hasanuddin, 2011)

Emzir. Metodologi Penelitian analisa Data. Jakarta: Raja Gravindo Persada, 2014. cet.4

Ema Salma. "Nilai-Nilai Islam Pada Bank Berbasis Syariah". (Skripsi, Universitas Alaudin Makasar, 2017).

Fahrian. Gadai Menurut KUHP. Dikutip dari www.jdih.tanahlautkab.co.id,2019

Henia Husna. "Pengaruh Penerapan Nilai-Nilai Islam Pada Bank BNI Syariah Banda aceh Terhadap Semangat Kerja Karyawan”. (Skripsi, Program Pascasarjana Universitas Islam Negeri Ar-Raniry Banda Aceh, 2018).

Http//www. Reseachgadai.co.id

H. Zainuddin Ali. Hukum Gadai Syariah. Jakarta: Sinar Grafika, 2008. cet. 1

Imam Abu zakaria Yahya Bin Syarif An-Nawawi Ad-Dimsyaqi, Riyadhus Sholihin. Terj. Abu Firly Basam Taqiy. Depok: Fathan, 2018

Katalog Produk Pegadaian Khusus Internal Pegadaian

M. Hariwijaya. Metodologi Penulisan Skripsi, Thesis, dan Disertasi Untuk Ilmu Sosial dan Humaniora. Yogyakarta. cet. 2

Mukhas. "Implementasi Gadai Syariah Dengan Akad Murabahah Dan Rahn". (Thesis. Program Pascasarjana Universitas Sebelah maret Surakarta, 2010.)

Nurul jempa, "Nilai-Nilai Agama Islam". (skripsi, Universitas Muhammadiyah Aceh, 2018)

Rozalinda. Fikih Ekonomi Syariah Prinsip dan Implementasinya Pada Sektor Keuangan Syariah. Jakarta: PT Raja Grafindo Persada, 2016. cet, 1

Samhi Muawan Djamal. "Penerapan Nilai-Nilai Ajaran Islam Dalam Kehidupan Masyarakat Di Desa Garuntungan Kecamatan rindang Kabupaten Bulukumba." (Skripsi, Universitas Islam Alauddin Makasar)

Sari Mulyani. "Analisis Praktik Akad Murabahah Di Bank Syariah Studi Kasus BRI Syariah KCP Rimbo Bujang". (Skripsi. Program Pascasarjana STAI YASNI Muara Bungo, 2018.) 
Rena, Ainil : Penerapan Nilai-Nilai Syariah...

Saryono dan Mekar Dwi Anggeraini. Metodologi Penelitian Kualitatif Dalam Bidang Kesehatan. Yogyakarta: Sorowajan Baru, Oktober 2011. cet,2

Sugiyono, Memahami Penelitian Kualitatif. Bandung: Alfabeta, 2007. `cet. 3

www.sahabatpegadaian.com

www.hadist.id

www.pegadaian.co.id 